\title{
THERMODYNAMIC CHARACTERIZATION OF DEXAMETHASONE SODIUM PHOSPHATE AND ITS COM- PLEX WITH DNA AS STUDIED BY CONDUCTOMETRIC AND SPECTROSCOPIC TECHNIQUES
}

\author{
AFZAL SHAH ${ }^{l}$, ASAD M. KHAN ${ }^{l}$, MUHAMMAD USMAN ${ }^{l}$, RUMANA QURESHI ${ }^{l}$, MUHAMMAD SIDDIQ ${ }^{l}$ \\ AND SYED S. SHAH
}

${ }^{1}$ Depar tment of Chemistry, Quaid-i-Azam University, 45320, Islamabad

(Received: July 28, 2008 -Accepted: April 7, 2009)

\begin{abstract}
Electrical conductivities were measured to calculate critical aggregation concentration (cac) of dexamethasone sodium phosphate (DSP) at various temperature from 298-313K with an increment of $5 \mathrm{~K}$ and in this way its thermodynamic parameters like Gibbs energy of aggregation $\left(\Delta \mathrm{G}_{\text {agg }}\right)$, enthalpy of aggregation $\left(\Delta \mathrm{H}_{\mathrm{agg}}\right)$ and entropy of aggregation $\left(\Delta \mathrm{S}_{\mathrm{agg}}\right)$ were estimated. The results demonstrate that DSP forms enthalpy driven aggregates through open association process. Furthermore, its interaction with DNA was studied by UV-Vis spectroscopy. The binding constant of DSP-DNA interaction was evaluated at $298 \mathrm{~K}$ and $310 \mathrm{~K}$. Gibbs energy of drug-DNA complexation was determined by $\Delta \mathrm{G}=-\mathrm{RT} \ln K_{\mathrm{b}}$, enthalpy of its interaction $(\Delta \mathrm{H})$ and entropy of adduct formation $(\Delta \mathrm{S})$ were obtained from Van't Hoff equation.
\end{abstract}

Keywords: dexamethasone, conductivity, binding constant, DNA, spectroscopy, aggregation

\section{INTRODUCTION}

Drugs having rigid aromatic or fused ring structures display an open or continuous association, which may, in no way be called micellization as it has no equivalence to critical micelle concentration $(\mathrm{cmc})^{1}$. Like such drugs dexamethasone sodium phoshate (DSP) also undergoes open or continuous aggregation that does not deserve to be regarded as micellization and inflection point may be called critical aggregation concentration (cac) rather than cmc. The experimental determination of specific conductivities is a promising technique for the detection of cac

The application of spectroscopic and conductometric techniques for complete thermodynamic profile of free and DNA bound drug is essential for getting insights into the molecular understanding of drug designing and binding affinities. The self-association of the drug and its complexation to DNA are dictated by entirely different driving forces. The development of correlation between macroscopic world of thermodynamics and microscopic world of structural data is essential for the manufacturing of cost effective drugs.

The investigation of drug-DNA interaction is important for further understanding of the drug action and molecular designing of DNA targeted drugs ${ }^{2}$. The drug -DNA interactions can be characterized by getting an insight into the structures of the complexes and the free energy contributions to the interactions. The thermodynamic characterization of DSP and its adduct with DNA, coupled with structural studies could be a new strategy in knowing the factors affecting the nature of interactions.

DSP (Scheme 1) is one of the widely used freely water-soluble drug with potent anti-inflammatory and antineoplatic activities. In the present work thermodynamic parameters of its self association and interaction with DNA have been determined by conductometric and UV-Vis spectroscopic techniques in a medium buffered at $\mathrm{pH} 7.4$ by using phosphate buffer $\left(0.1 \mathrm{M} \mathrm{KH}_{2} \mathrm{PO}_{4}\right.$ and 0.1 $\mathrm{M} \mathrm{NaOH})$.

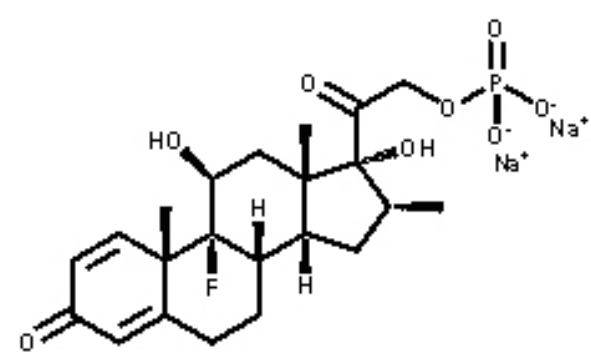
(DSP)

Scheme 1.- Molecular structure of Dexamethasone sodium phosphate

\section{EXPERIMENTAL SECTION}

Reagents

Dexamethasone sodium phosphate abbreviated as DSP (Q.C number 0807532 and batch number MLDP 070307, pharmaceutical grade) was ob- tained from leads pharma I/10-3 Islamabad, Pakistan.

DNA was extracted from chicken blood by Falcon method ${ }^{3}$. Stock solution of DNA was prepared by dissolving an appropriate amount of DNA in doubly distilled water and stored at $4^{\circ} \mathrm{C}$. The concentration of the stock solution of DNA ( $3 \mathrm{mM}$ in Nucleotide Phosphate, NP) was determined by UV absorbance at $260 \mathrm{~nm}$ using the molar extinction coefficient (C) of $6600 \mathrm{M}^{-1} \mathrm{~cm}^{-14}$.

The $\mathrm{N} / \mathrm{P}$ ratio of $1.85\left(\mathrm{~A}_{260} / \mathrm{A}_{280}=1.85\right)$ was taken as evidence for protein free DNA ${ }^{5}$. Stock solution of DSP $(5 \mathrm{mM})$ was prepared by dissolving it in distilled water.

\section{Apparatus}

Conductivities were measured using Jenway 4310 conductometer in the temperature range $298-313 \mathrm{~K}$, with $5 \mathrm{~K}$ increment. The electrode was calibrated using $\mathrm{KCl}$, over the appropriate concentration range. The temperature was controlled using a water circulator (Irmeco I-1800). Absorption spectra were measured on a UV-Vis Spectrometer; Shimadzu 1601.

\section{Theory}

Specific Conductivities

The self aggregation of DSP is studied by a fundamental quantity, the critical aggregation concentration (cac). The experimental determination of specific conductivities provides more scientific technique to detect cac. According to William et. al., ${ }^{6}$ the inflection point can be determined by intersection of two straight lines of concentration-conductivity plot, above and below cac. The precision of measurement depends on the width of concentration range over which the change in physical properties are observed. The values of the Gibbs free energy of aggregation, $\Delta \mathrm{G}_{\mathrm{agg}}^{\circ}$ was calculated from the expression given as:

$$
\Delta \mathrm{G}_{\mathrm{agg}}^{0}=(1+\alpha) R T \ln \mathrm{X}_{\mathrm{cac}}
$$

where $\alpha$ is degree of counter ion binding given as $\alpha=1-\beta$ and $\beta$ is degree of ionization calculated by the ratio of slopes of post aggregation and pre aggregation phases following Evans ${ }^{7}$ as $\beta=S_{2} / S_{1}$, where $S_{2}$ and $S_{1}$ are the slope of post aggregation and pre aggregation phases, respectively. In Equation 1, $\mathrm{X}_{\mathrm{cac}}$ is critical aggregation concentration expressed in mole fraction unit.

Whereas, Enthalpy of aggregation, $\Delta \mathrm{H}_{\mathrm{agg}}$ and Entropy of aggregation, $\Delta \mathrm{S}_{\mathrm{agg}}^{\circ}$ were calculated from conductivity data using Equations 2 and 3 :

$$
\begin{gathered}
\Delta \mathrm{H}_{\mathrm{agg}}^{\circ}=-2.3 \mathrm{RT}^{2}\left[\frac{\partial(1+\alpha)\left(\log \mathrm{X}_{\mathrm{cac}}\right)}{\partial \mathrm{T}}\right]_{\mathrm{P}} \\
\Delta \mathrm{S}_{\mathrm{agg}}^{\circ}=\frac{\Delta \mathrm{H}_{\mathrm{agg}}^{\circ}-\Delta \mathrm{G}_{\mathrm{agg}}^{\circ}}{\mathrm{T}}
\end{gathered}
$$

\section{RESULTS AND DISCUSSION}

Electrical Conductivity studies

DSP has rigid aromatic structure and undergoes open or continuous aggregation. As such aggregation does not deserve to be regarded as micellization and inflection point may be called critical aggregation concentration (cac) 
instead of critical micelle concentration (cmc).

Figure 1. shows the concentration dependence of electrical conductivity of DSP at various temperatures. As drug has fused ring structure so critical aggregation concentration (cac) is not a sharp point and was determined using linear regression of the two data series ${ }^{8}$. The value of cac increases with increase in the temperature due to increase in solubility and decrease in hydration of hydrophilic groups which enhances repulsion between them, making aggregation difficult and thus increasing cac value.

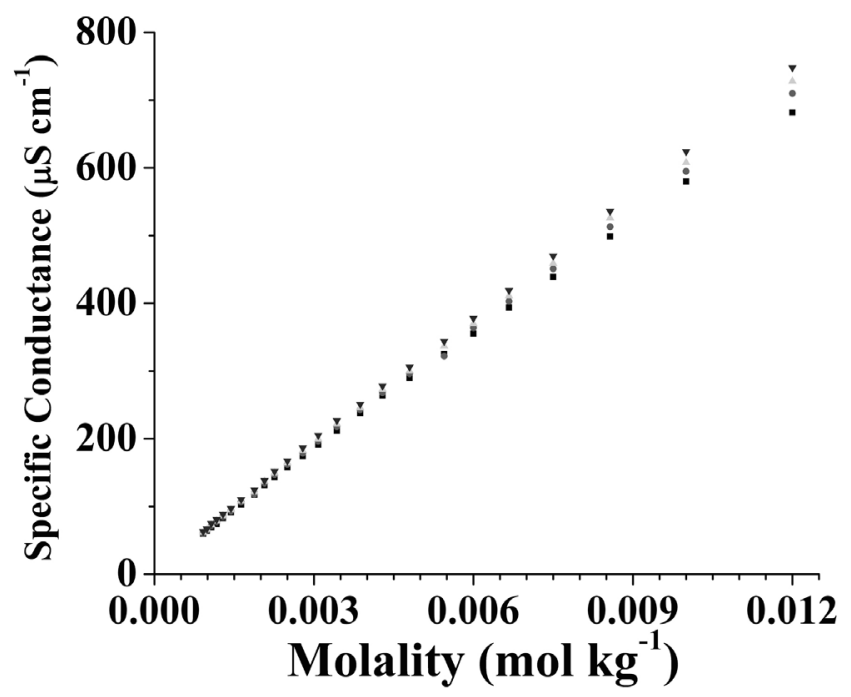

Fig. 1.- The plot of Conductivity (micro Seimen) versus molality, m, (mol $\left.\mathrm{kg}^{-1}\right)$, for aqueous solution of Dexa methasone Sodium Phosphate at $25^{\circ} \mathrm{C}(\mathbf{\bullet})$, $30^{\circ} \mathrm{C}(\bullet), 35^{\circ} \mathrm{C}(\boldsymbol{\Delta})$ and $40^{\circ} \mathrm{C}(\boldsymbol{\nabla})$.

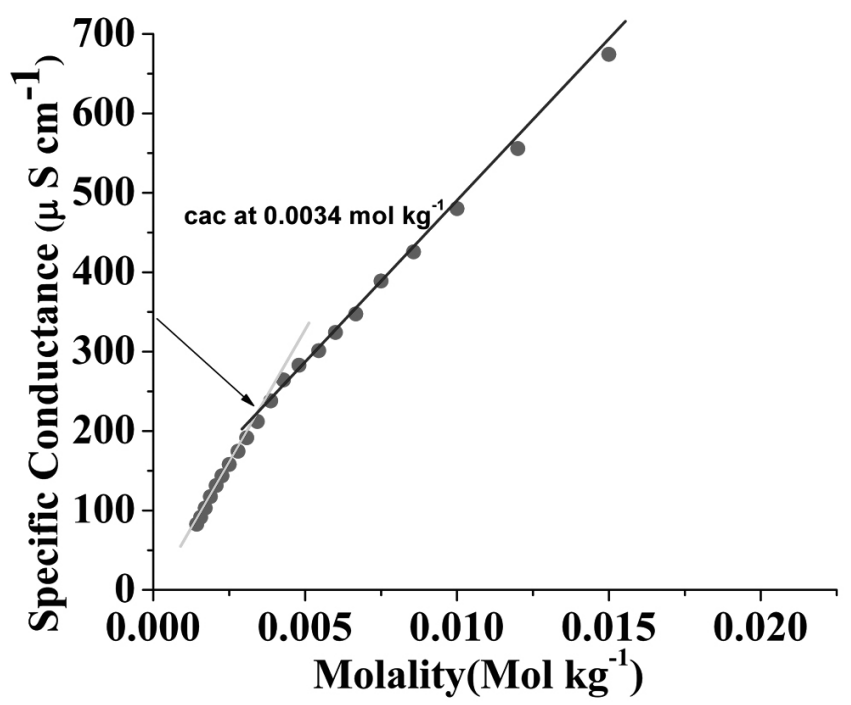

Fig. 2.- The plot of electrical conductivity $\left(\mu \mathrm{S} \mathrm{cm}^{-1}\right)$ versus molality,(mol $\mathrm{kg}^{-1}$ ), for aqueous solution of DSP at $298 \mathrm{~K}$ showing $\mathrm{cmc}$ at $0.0034 \mathrm{~mol} / \mathrm{kg}$.

The increasing trend of cac with temperature shows aggregation becomes difficult as temperature increases. Gibbs free energy of aggregation becomes less negative with temperature, showing that the process becomes less spontaneous as temperature increases. Similarly lower magnitude of negative value of enthalpy and entropy of aggregation is another evidence of no spontaneity of aggregation at high temperature. Degree of ionization $(\beta)$ is promoted while degree of counter ion binding $(\alpha)$ is lowered with rise in temperature increasing repulsion between ionic heads thus making aggregation difficult. The thermodynamic parameters calculated from cac value are given in Table 1. typical change in electrical conductivity versus concentration is demonstrated in Figure 2 showing cac at $3.40( \pm 0.14) \times 10^{-3} \mathrm{~mol} / \mathrm{kg}$ at $298 \mathrm{~K}$.

The critical concentration of DSP increases with rise in temperature due to greater dehydration of polar head groups than those of hydrophobic groups. The dehydration of polar head groups leads to repulsion between them which make the aggregation difficult and cause increase in critical concentration ${ }^{9}$. Gibbs free energy is negative and becomes more negative with fall in temperature. This indicates that the process becomes more spontaneous at lower temperature. This fact is also confirmed by the decrease in cac with the decrease in temperature. The negative values of $\Delta \mathrm{H}$ and $\Delta \mathrm{S}$ at all temperature indicate the aggregation process to be enthalpy driven. The negative value of $\Delta \mathrm{S}$ shows that aggregation is not an entropy-driven process. It could be due to more pronounced ordering effect of the randomly oriented monomers from solvated form into highly organized core of aggregate than disordering effect caused by destruction of water structure around hydrophobic groups of monomer molecule. Moreover, the highly negative value of $\Delta \mathrm{H}$ is indicative of greater contribution of electrostatic interactions during aggregation ${ }^{9}$.

Spectroscopic studies

Spectroscopic titrations of DSP with solution phase DNA were carried out in a medium buffered at $\mathrm{pH} 7.4$ by using phosphate buffer $\left(0.1 \mathrm{M} \mathrm{KH}_{2} \mathrm{PO}_{4}\right.$ and $0.1 \mathrm{M} \mathrm{NaOH}$ ). The solutions were allowed to equilibrate for $5 \mathrm{~min}$ before every experimental assay. In the present investigations, the interaction of DSP with double stranded-DNA in aqueous solution has been monitored. The absorbance measurements were performed by keeping the concentration of the drug constant $(50 \mu \mathrm{M})$ while varying the concentration of DNA from $10 \mu \mathrm{M}$ to $200 \mu \mathrm{M}$.

Table 1.- Different Thermodynamic parameters obtained from Conductivity data.

\begin{tabular}{|c|c|c|c|c|c|}
\hline $\begin{array}{l}\text { Temp. } \\
\text { (K) }\end{array}$ & $\begin{array}{c}\text { cac } \\
\left(\mathrm{mol} \mathrm{kg}^{-1}\right)\end{array}$ & $\begin{array}{c}\Delta \mathrm{H}_{\mathrm{agg}} \\
\left(\mathrm{kJ} \mathrm{mol}^{-1}\right)\end{array}$ & $\begin{array}{c}\Delta \mathrm{G}_{\mathrm{agg}} \\
\left(\mathrm{kJ} \mathrm{mol}^{-1}\right)\end{array}$ & $\begin{array}{c}\Delta \mathbf{S}_{\mathrm{agg}} \\
(\mathbf{k J} \\
\left.\mathbf{K}^{-1} \mathbf{m o l}^{-1}\right)\end{array}$ & $\alpha^{a}$ \\
\hline 298 & $\begin{aligned} 3.40 & ( \pm 0.14) \\
\times & 10^{-3}\end{aligned}$ & $\begin{array}{c}-46.31 \\
( \pm 0.83)\end{array}$ & $\begin{array}{c}-26.69 \\
( \pm 0.27)\end{array}$ & $\begin{array}{c}-6.58 \\
( \pm 0.18) \times \\
10^{-2}\end{array}$ & 0.11 \\
\hline 303 & $\begin{array}{c}4.79( \pm 0.24) \\
\times 10^{-3}\end{array}$ & $\begin{array}{c}-48.70 \\
( \pm 0.78)\end{array}$ & $\begin{array}{c}-25.84 \\
( \pm 0.21)\end{array}$ & $\begin{array}{c}-7.55 \\
( \pm 0.15) \times \\
10^{-2}\end{array}$ & 0.10 \\
\hline 308 & $\begin{array}{c}6.91( \pm 0.20) \\
\times 10^{-3}\end{array}$ & $\begin{array}{c}-51.13 \\
( \pm 0.71)\end{array}$ & $\begin{array}{c}-25.08 \\
( \pm 0.18)\end{array}$ & $\begin{array}{c}-8.47 \\
( \pm 0.17) \times \\
10^{-2}\end{array}$ & 0.09 \\
\hline 313 & $\begin{array}{c}7.87( \pm 0.31) \\
\times 10^{-3}\end{array}$ & $\begin{array}{c}-53.62 \\
( \pm 1.02)\end{array}$ & $\begin{array}{l}-24.85 \\
( \pm 0.16)\end{array}$ & $\begin{array}{c}-9.19 \\
( \pm 0.19) \times \\
10^{-2}\end{array}$ & 0.08 \\
\hline
\end{tabular}

${ }^{\mathrm{a}} \alpha=$ Degree of counter ion binding

The spectrum recorded slight bathochromic and profound hypochromic effects by the addition of DNA. These observations are attributable to the intercalation of DSP with DNA ${ }^{10}$. The UV-Vis spectrum (Figure. 3) of the drug showed a $3 \mathrm{~nm}$ red shift from $243 \mathrm{~nm}$ to $246 \mathrm{~nm}$, accompanied with a $37.4 \%$ decrease in absorbance of the initial value. The hypochromism is due to the strong interaction between the electronic states of the DSP chromophore with the bases of DNA ${ }^{9,102}$. Such changes in drug absorption properties as a function of DNA binding were used for the evaluation of the binding constant $\left(K_{b}\right)$ by using the following equation ${ }^{11-146}$ :

$$
\frac{\mathrm{A}_{0}}{\mathrm{~A}-\mathrm{A}_{0}}=\frac{\varepsilon_{\mathrm{G}}}{\varepsilon_{\mathrm{H}-\mathrm{G}}-\varepsilon_{\mathrm{G}}}+\frac{\varepsilon_{\mathrm{G}}}{\varepsilon_{\mathrm{H}-\mathrm{G}}-\varepsilon_{\mathrm{G}}} \cdot \frac{1}{\mathrm{~K}_{\mathrm{b}}[\mathrm{DNA}]}
$$

Where $\mathrm{K}_{\mathrm{b}}$ is the binding constant, $\mathrm{A}_{0}$ and $\mathrm{A}$ are absorbances of the drug and the apparent one, $\varepsilon_{\mathrm{G}}$ and $\varepsilon_{\mathrm{H}-\mathrm{G}}$ are their absorption coefficients respectively. 


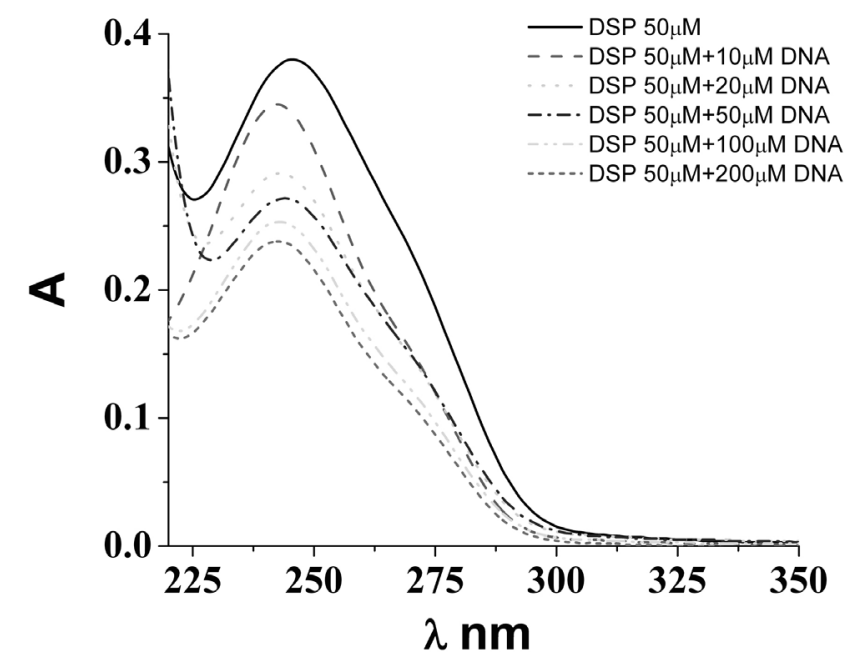

Fig. 3.- Representative absorption spectra of $50 \mu \mathrm{M}$ DSP in the absence and presence of varying concentration of DNA at $298 \mathrm{~K}$ in a medium buffered at $\mathrm{pH} 7.4$.

The binding constant $\mathrm{K}_{\mathrm{b}}\left(8.43 \times 10^{4} \mathrm{M}^{-1}\right)$ was obtained from intercept to slope ratio of $\mathrm{A}_{0} /\left(\mathrm{A}-\mathrm{A}_{0}\right)$ vs. 1/[DNA] plot (Figure 4.) at $298 \mathrm{~K}$. The value of binding constant obtained here is about twice as the value of $\mathrm{K}_{\mathrm{b}}$ for the interaction of proflavin $\left(4.86 \times 10^{4} \mathrm{M}^{-1}\right)$ with DNA ${ }^{11}$. The binding constant with a value of $2.53 \times 10^{5}$ was obtained at body temperature $(310 \mathrm{k})$. The increase in binding constant at high temperature may be attributed to the overall stability of the drug-DNA adduct. This reveals that the geometry of the drug-DNA complex contributes to anticancer behavior more than the binding affinity. The Gibbs energy change of $-28.10 \mathrm{~kJ} \mathrm{~mol}^{-1}$ and -32.06 at both the above temperatures indicate the spontaneity of drug-DNA binding.

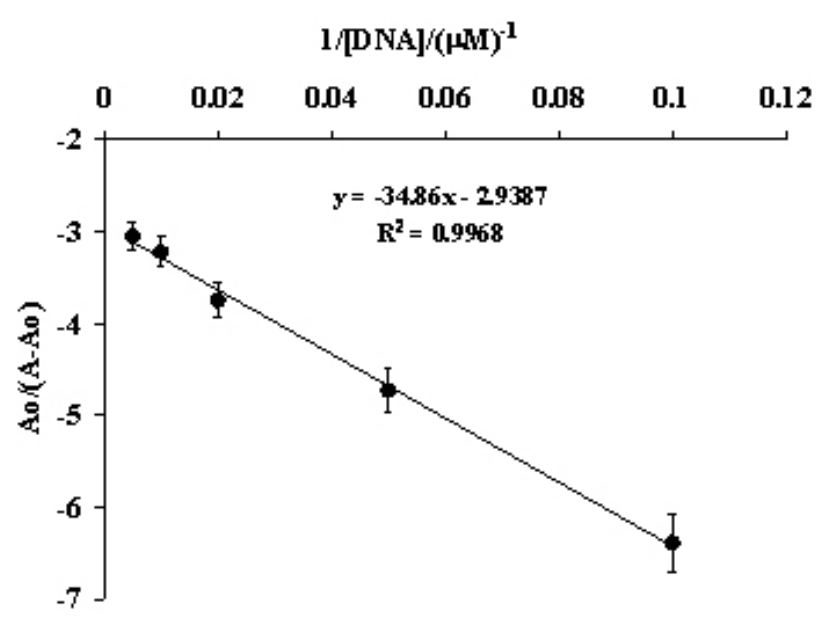

Fig. 4.- Plot of Ao/(A-Ao) versus 1/[DNA] for the determination of binding constant by the addition of $10,20,50,100$ and $200 \mu \mathrm{M}$ DNA in constant amount of the drug $(50 \mu \mathrm{M})$ at $298 \mathrm{~K}$ and $7.4 \mathrm{pH}$. Error bars were drawn for $5 \%$ fluctuation in UV absorbance data.

However the correct mechanism of drug-DNA binding in eliciting antitumor effects remains unresolved due to the reversible nature of drug-DNA complexes, which demands for increased drug level in order to achieve the steady state condition required for detection and thus limits the resolution of such studies apart from additional non specific biologically irrelevant interactions. Efforts are currently underway to circumvent such problems by the use of different techniques.

For the evaluation of thermodynamic parameters of DSP-DNA adduct, the binding constant values were converted to Gibbs energy changes by the expression:

$$
\Delta \mathrm{G}=-\mathrm{RT} \ln K_{b}
$$

Inspection of table 2 unequivocally reflects an increase in the value of binding constant with the increase in temperature. This thermodynamic stabilization of the drug-DNA complex with the increase in temperature can better be explained by the likely overall conformational changes in the whole structure of the conjugate rather than the additional local interaction.

Enthalpy of complex formation $(\Delta \mathrm{H})$ with a value of $65.07 \mathrm{~kJ} / \mathrm{mol}$ was determined by the application of Van't Hoff equation:

$$
\ln K_{b}=-\Delta H / R T+\Delta S / R
$$

$\Delta \mathrm{H}$ and $\Delta \mathrm{S}$ were calculated from the slope and intercept of the plot of $\ln K_{b}$ versus $1 / T$. The positive values of both $\Delta S$ indicates that DSP interactions with DNA are entropy driven. The high enthalpy value for the complex formation was just the consequence of the interaction between two negatively charged species. The $\Delta \mathrm{H}$ measured is the total enthalpy change which includes heat associated with processes such as formation of non-covalent bonds between interacting molecules and with other equilibria in the system such as conformational changes, ionization of polar groups and changes due to interactions with solvent. By the identification of these specific effects the apparent $\Delta H$ can be reported which will be helpful in distinguishing binding effects more precisely from related conformational and solvent effects.

Table 2.- Thermodynamic parameters obtained from UV-Vis spectroscopic data of DSP-DNA interaction.

\begin{tabular}{|c|c|c|c|c|}
\hline $\begin{array}{c}\text { Temp } \\
(\mathbf{K})\end{array}$ & $\begin{array}{c}\text { Binding Constant } \\
\left(\boldsymbol{K}_{b}\right) \mathbf{M}^{-1}\end{array}$ & $\begin{array}{c}\Delta \mathbf{G} \\
\left(\mathbf{k J ~ m o l}^{-1}\right)\end{array}$ & $\begin{array}{c}\Delta \mathbf{H} \\
(\mathbf{k J} \\
\left.\mathbf{m o l}^{-1}\right)\end{array}$ & $\begin{array}{c}\Delta \mathbf{S} \\
(\mathbf{k J} \\
\left.\mathbf{K}^{-1} \mathbf{m o l}^{-1}\right)\end{array}$ \\
\cline { 1 - 2 } 288 & $3.67( \pm 0.18) \times 10^{4}$ & $\begin{array}{c}-25.17 \\
( \pm 1.13)\end{array}$ & & \\
\cline { 1 - 2 } 293 & $5.84( \pm 0.25) \times 10^{4}$ & $\begin{array}{c}-26.74 \\
( \pm 1.20)\end{array}$ & \multirow{2}{*}{65.07} & $\begin{array}{c}0.31 \\
( \pm 3.45)\end{array}$ \\
\cline { 1 - 3 } 298 & $8.43( \pm 0.29) \times 10^{4}$ & $\begin{array}{c}-28.10 \\
( \pm 1.15)\end{array}$ & & \\
\cline { 1 - 2 } 310 & $2.53( \pm 0.10) \times 10^{5}$ & $\begin{array}{c}-32.06 \\
( \pm 1.47)\end{array}$ & & \\
\hline
\end{tabular}

The negative values of $\Delta \mathrm{G}$ indicate that drug-DNA complexation is a spontaneous process. Thus the overall stability of drug-DNA complex is dictated by Gibbs free energy change $\Delta \mathrm{G}$ that involves both enthalpic and entropic contributions.

\section{CONCLUSIONS}

Thermodynamic properties were calculated from critical aggregation concentration (cac). The results indicate increase of cac value with rise in temperature due to enhancement in solubility and dehydration of hydrophilic groups as a result of their more repulsion which makes the aggregation difficult thus resulting in increased cac. The trend of $\Delta \mathrm{G}_{\mathrm{agg}}$ and $\Delta \mathrm{H}_{\mathrm{agg}}$ unfolds the fact that the enthalpy driven process of aggregation becomes less spontaneous with rise in temperature.

Spectroscopic results manifest that DSP interacts with DNA via intercalative mode of binding. The increase in binding constant at relatively high temperature suggests thermodynamic stabilization of the drug-DNA complex due to the likely overall conformational changes in the whole structure of the adduct rather than the additional local interaction.

The positive values of $\Delta \mathrm{S}$ indicate that DSP interactions with DNA are entropy driven. The high enthalpy value for the complex formation was the consequence of the interaction between two negatively charged species. 


\section{REFERENCES}

1. D. Attwood, Adv. Colloid Interface Sci. 55, 271, (1995).

2. R. K. Gilpin, Anal. Chem. 69, 145R, (1997).

3. J. Sambrook, E. F. Fritsch, T. Maniatis, Molecular Cloning: A Laboratory Manual, Cold Spring Harbor, New York, 1989.

4. X. Jiang, X. Lin, Bioelectrochemistry. 68, 206, (2006).

5. S. S. Babkina, N. A. Ulakhovich, Anal. Chem. 77, 5678, (2005).

6. R. J. Williams, J. N. Phillips, K. J. Mysels, Trans. Faraday. Soc. 51, 728, (1955).
7. H. C. Evans, J.Chem.Soc. 60, 579 (1956).

8. A. M. Khan, S. S. Shah, J. Chem. Soc. Pak. 30, 186, (2008).

9. C. V. Kumar, E. H. Asuncion, J. Am. Chem. Soc. 115, 8547, (1993).

10. M. Kozurková, D. Sabolová, L. Janovec, J. Mikes, J. Koval, J. Ungvarský, M. Stefanisinová, P. Fedorocko, P. Kristian, J. Imrich, Bioorg. Med. Chem. 16, 3976, (2008).

11. M. Aslanoglu, Anal. Sci. 22, 439, (2006).

12. X. J. Dang, J. Tong, H. L. Li, J. Inclusion Phenom. 24, 275, (1996).

13. J. B. Lepecq, C. Paoletti, J. Mol. Biol. 27, 87, (1967).

14. M. Y. Nie, Y. Wang, H. L. Li, Pol. J. Chem. 71, 816, (1997). 